\title{
Multiple Myeloma Index for Risk of Infection
}

\author{
Valkovic $\mathrm{T}^{1}$, Gacic $\mathrm{V}^{2}$, Nacinovic-Duletic $\mathrm{A}^{1 凶}$ \\ 1. Department of Hematology, Rheumatology and Clinical Immunology, University Hospital Center Rijeka and School of Medicine Rijeka, Croatia \\ 2. Department of Hematology, University Hospital Center Mostar, Bosnia and Hercegovina \\ $\triangle$ Corresponding author: Toni Valkovic, MD, PhD, Professor, Department of Hematology, Rheumatology and Clinical Immunology, University Hospital \\ Center Rijeka and School of Medicine Rijeka, Kresimirova 42, 51000 Rijeka, Croatia. Telephone: 0038551658185; Fax: 0038551658826; e-mail: toni_val@net.hr \\ (C) Ivyspring International Publisher. This is an open access article distributed under the terms of the Creative Commons Attribution (CC BY-NC) license \\ (https://creativecommons.org/licenses/by-nc/4.0/). See http://ivyspring.com/terms for full terms and conditions.
}

Received: 2017.12.10; Accepted: 2018.02.10; Published: 2018.06.04

\begin{abstract}
Based on our earlier research into the main characteristics and risk factors for infections in hospitalized patients with multiple myeloma, we created the numerical Multiple Myeloma Index for Risk of Infection (MMIRI) to predict infection in myeloma patients. The included factors that could influence the pathogenesis and incidence of infections were sex, performance status, Durie Salmon stage of disease, International Staging System, serum creatinine level, immune paresis, neutropenia, serum ferritin level, the presence of any catheters, disease duration, stable/progressive disease, and type of therapy. For each of these parameters, the strength of association with infection was statistically estimated and specific number of points was assigned to each of these parameters, proportional to the strength of the association. When designing the MMIRI, we included only those parameters that we determined were pathophysiologically associated with the infection. After further statistical analysis, we identified an optimal cutoff score of 6 or above as indicating a significant risk for infection, with a sensitivity of $93.2 \%$ and specificity of $80.2 \%$. The scoring system in the retrospective receiver operating characteristic analysis showed an area under the curve of 0.918 . The potential value of the MMIRI is the possibility of identifying those patients who would benefit from the prophylactic administration of antibiotics and other anti-infective measures while minimizing the contribution to antibiotic resistance related to the overuse of these drugs. As far as we know, this index represents the first attempt to create such an instrument for predicting the occurrence of infections in myeloma patients.
\end{abstract}

\section{Introduction}

The intrinsic immune dysfunction in combination with therapy-related immunosuppression leads to an increased risk for infections, which is a hallmark of multiple myeloma (MM) and major cause of mortality [1-5]. Furthermore, the infection itself can pathogenetically contribute to the progression of MM through different mechanisms, such as robust production of promyeloma cytokines (e.g., interleukin-6) and activation of Toll-like receptors on malignant plasma cells [6-10]. Today, with the advent of several new and effective antimyeloma drugs and increased overall survival, preventing death from infections becomes paramount. We tried to create the numerical Multiple Myeloma Index for Risk of Infection (MMIRI) to predict infection in myeloma patients and help identify patients who have a higher risk for developing infections.

\section{Materials and Methods}

To develop the index, we used our earlier research into the main characteristics and risk factors for infections in hospitalized patients with MM [11]: we took retrospective data from hospital medical documentation for 240 cases of hospitalized patients with MM (120 males and 120 females; average age of 69 , range of 41-89 years) who were diagnosed or treated in our Department from January 2008 to December 2010. Because the majority of patients were hospitalized more than once, the total number of our 
cases was larger than the number of patients included in this study (37 males and 35 females, respectively). Only patients who were not treated with autologous or allogeneic hematopoietic stem cell transplant were included. The diagnosis was established according to International Myeloma Working Group criteria [12]. The great majority of patients in this study had IgG, IgA, or a light-chain myeloma; however, one patient with $\operatorname{IgD}$ and one with nonsecretory myeloma were also included [11]. Our patients were treated fairly uniformly at the time of this study: vincristine, doxorubicin, and dexamethasone and oral melphalan and prednisone regimens were mostly used as induction therapy (according to patient age and eligibility for high-dose therapy), with thalidomide-based protocols as second-line therapy and bortezomib-based protocols as third- or next-line therapy. In some patients, monotherapy with dexamethasone was used as a front-line therapy, as well as for postinduction [11]. The study was approved by the Medical School of Rijeka Ethics Committee.

The criteria for infection used in our study were increased body temperature above the normal range $\left(37^{\circ} \mathrm{C}\right)$ or isolation of a microbial agent in patients who also had concomitant clinical symptoms and/or humoral signs of infection (leukocytosis, neutrophilia, marked "left shift," or increased C-reactive protein in comparison with a baseline value) [11]. The included factors that could influence the pathogenesis and incidence of infections were sex, performance status [13], Durie Salmon stage of disease [14], International Staging System [15], serum creatinine level (normal or increased), immune paresis defined qualitatively (decreased serum concentration of any polyclonal Ig class), neutropenia (defined as blood neutrophil count of $\leq 2 \times 10^{9} / \mathrm{L}$ ), serum ferritin level (normal; moderately increased; extremely increased), the presence of any catheters, disease duration, stable/progressive disease, and type of therapy. The number of cases, age, sex, and duration of disease for MM patients with and without infections are presented in Table 1 . The characteristics of tested parameters are shown in Table 2 [11].

For each of these parameters, the strength of association with infection was statistically estimated. When designing the MMIRI, we included only those parameters that we determined were pathophysiologically associated with the infection. A specific number of points was assigned to each of these parameters, proportional to the strength of the statistical association. Statistical association between nominal variables was measured by Cramer's V coefficient, whereby a minimum coefficient value of 0.15 was required. For the scoring system, the coefficient values were divided by a minimum value and rounded to the nearest integer. The cutoff value of the scoring system was determined by optimization of sensitivity and specificity based on the Youden index together with classical receiver operating characteristic analysis.

Table 1. Main cases characteristics

\begin{tabular}{llll}
\hline & With infections & Without infections & Total \\
\hline Number of cases & 43 & 197 & 240 \\
Age, median (range) & $65(41-89)$ & $69(41-86)$ & $69(41-89)$ \\
Sex (male/female), $\mathrm{n}$ & $9 / 34$ & $111 / 86$ & $120 / 120$ \\
$\begin{array}{l}\text { Disease duration } \\
\text { (months), median (range) }\end{array}$ & $26(1-121)$ & $7(1-150)$ & $8(1-150)$ \\
\hline
\end{tabular}

Table 2. Characteristics of tested parameters

\begin{tabular}{|c|c|c|c|c|}
\hline \multicolumn{2}{|c|}{ Tested Parameters } & \multirow[t]{2}{*}{$\begin{array}{l}\begin{array}{l}\text { Number } \\
\text { of Cases }\end{array} \\
120\end{array}$} & \multirow{2}{*}{$\begin{array}{l}\text { Group } \\
\text { without } \\
\text { Infections } \\
111\end{array}$} & \multirow{2}{*}{$\begin{array}{l}\text { Group } \\
\text { with } \\
\text { Infections } \\
9\end{array}$} \\
\hline Sex & Male & & & \\
\hline & Female & 120 & 86 & 34 \\
\hline \multirow{5}{*}{$\begin{array}{l}\text { ECOG } \\
\text { performance } \\
\text { status }\end{array}$} & 0 & 16 & 16 & 0 \\
\hline & 1 & 88 & 85 & 3 \\
\hline & 2 & 70 & 60 & 10 \\
\hline & 3 & 45 & 30 & 15 \\
\hline & 4 & 20 & 5 & 15 \\
\hline \multirow{5}{*}{$\begin{array}{l}\text { Durie-Salmon } \\
\text { stage of disease }\end{array}$} & $1 \mathrm{~A}$ & 6 & 5 & 1 \\
\hline & $2 \mathrm{~A}$ & 51 & 47 & 4 \\
\hline & $2 B$ & 1 & 0 & 1 \\
\hline & $3 \mathrm{~A}$ & 106 & 89 & 17 \\
\hline & 3B & 59 & 40 & 19 \\
\hline \multirow{3}{*}{$\begin{array}{l}\text { International } \\
\text { Staging } \\
\text { System }\end{array}$} & 1 & 54 & 44 & 10 \\
\hline & 2 & 57 & 50 & 7 \\
\hline & 3 & 98 & 81 & 17 \\
\hline \multirow[t]{3}{*}{$\begin{array}{l}\text { Serum } \\
\text { creatinine level }\end{array}$} & $\begin{array}{l}\leq 100 \mathrm{mmol} / \mathrm{L}(\mathrm{f}) ; \leq 120 \mathrm{mmol} / \mathrm{L} \\
(\mathrm{m}) \text { (normal value) }\end{array}$ & 133 & 117 & 16 \\
\hline & $\begin{array}{l}>100 \leq 175 \mathrm{mmol} / \mathrm{L}(\mathrm{f}) ;>120 \leq 175 \\
\mathrm{mmol} / \mathrm{L}(\mathrm{m})\end{array}$ & 52 & 41 & 11 \\
\hline & $>175 \mathrm{mmol} / \mathrm{l}(\mathrm{f}, \mathrm{m})$ & 49 & 35 & 14 \\
\hline \multirow[t]{3}{*}{ Immuneparesis } & Yes & 184 & 148 & 36 \\
\hline & No & 46 & 40 & 6 \\
\hline & No & 160 & 138 & 22 \\
\hline \multirow[t]{3}{*}{ Neutropenia } & $1.01-2 \times 10^{9} / \mathrm{L}$ & 55 & 44 & 11 \\
\hline & $0.51-1 \times 10^{9} / \mathrm{L}$ & 14 & 8 & 6 \\
\hline & $<0.5 \times 10^{9} / \mathrm{L}$ & 3 & 1 & 2 \\
\hline \multirow{3}{*}{$\begin{array}{l}\text { Serum ferritin } \\
\text { level }\end{array}$} & $\leq 120 \mu \mathrm{g} / \mathrm{L}(\mathrm{f}) ; \leq 300 \mu \mathrm{g} / \mathrm{L}(\mathrm{m})$ & 51 & 46 & 5 \\
\hline & $\begin{array}{l}>120 \leq 240 \mu \mathrm{g} / \mathrm{L}(\mathrm{f}) ;>300 \leq 600 \\
\mu \mathrm{g} / \mathrm{L}(\mathrm{m})\end{array}$ & 19 & 16 & 3 \\
\hline & $>240 \mu \mathrm{g} / \mathrm{L}(\mathrm{f}) ;>600 \mu \mathrm{g} / \mathrm{L}(\mathrm{m})$ & 32 & 18 & 14 \\
\hline \multirow{7}{*}{$\begin{array}{l}\text { Types of } \\
\text { therapy }\end{array}$} & Without therapy & 39 & 32 & 7 \\
\hline & VAD & 76 & 71 & 5 \\
\hline & MP & 13 & 11 & 2 \\
\hline & Thalidomide-based & 20 & 17 & 3 \\
\hline & Dexamethasone & 55 & 48 & 7 \\
\hline & Bortezomib-based & 28 & 14 & 14 \\
\hline & Others & 5 & 1 & 4 \\
\hline \multirow{6}{*}{$\begin{array}{l}\text { Presence of any } \\
\text { catheters }\end{array}$} & Without catheters & 190 & 179 & 11 \\
\hline & $\mathrm{UC}$ & 32 & 22 & 10 \\
\hline & $\mathrm{CVC}$ & 2 & 2 & 0 \\
\hline & UC, CVC, ITC & 2 & 0 & 2 \\
\hline & CVC, ITC & 1 & 1 & 0 \\
\hline & $\mathrm{UC}, \mathrm{CVC}$ & 8 & 0 & 8 \\
\hline
\end{tabular}

f: female, m: male; VAD: vincristine, doxorubicin, dexamethasone, MP: oral melphalan and prednisone, UC: urinary catheter, CVC: central venous catheter, ITC: intrathoracic catheter 


\section{Results}

We provide the relevant parameters associated with infections in the statistical analysis and the corresponding number of points assigned in the MMIRI in Table 3. Some other parameters, such as immune paresis and the International Staging System, showed no association with infections, and the parameters of sex and type of therapy were excluded from further analysis based on our determination that they were not useful. With these adjustments, we identified an optimal cutoff score of 6 or above as indicating a significant risk for infection, with a sensitivity of $93.2 \%$ and specificity of $80.2 \%$. The scoring system in the retrospective receiver operating characteristic analysis showed an area under the curve of $0.918(\mathrm{p}<0.0001$; Figure 1).

Table 3. Parameters associated with infections included in the MMIRI point system with corresponding points assigned for each parameter

\begin{tabular}{|c|c|c|}
\hline Parameter & Cramer V coefficient & Points \\
\hline $\begin{array}{l}\text { Longer duration of disease } \\
\text { (>8 months) }\end{array}$ & 0.2326 & 2 \\
\hline $\begin{array}{l}\text { Durie Salmon Clinical } \\
\text { Stage 3B }\end{array}$ & 0.1975 & 1 \\
\hline ECOG0 and 1 & -0.2935 & -2 \\
\hline ECOG2 & -0.0671 & 0 \\
\hline ECOG3 & 0.1862 & 1 \\
\hline ECOG4 & 0.4416 & 3 \\
\hline Presence of catheter & 0.6539 & 5 \\
\hline Elevated creatinine value & 0.1545 & 1 \\
\hline $\begin{array}{l}\text { Moderately elevated ferritin } \\
\text { value: } \\
>120 \text { to } \leq 240 \mu \mathrm{g} / \mathrm{L} \text { (f) } \\
>300 \text { to } \leq 600 \mu \mathrm{g} / \mathrm{L}(\mathrm{m})\end{array}$ & 0.3012 & 2 \\
\hline $\begin{array}{l}\text { Extremely elevated ferritin value: } \\
>240 \mu \mathrm{g} / \mathrm{L} \text { (f) } \\
>600 \mu \mathrm{g} / \mathrm{L}(\mathrm{m})\end{array}$ & 0.3834 & 3 \\
\hline Neutropenia & 0.1418 & 1 \\
\hline Progressive disease & 0.3206 & 2 \\
\hline
\end{tabular}

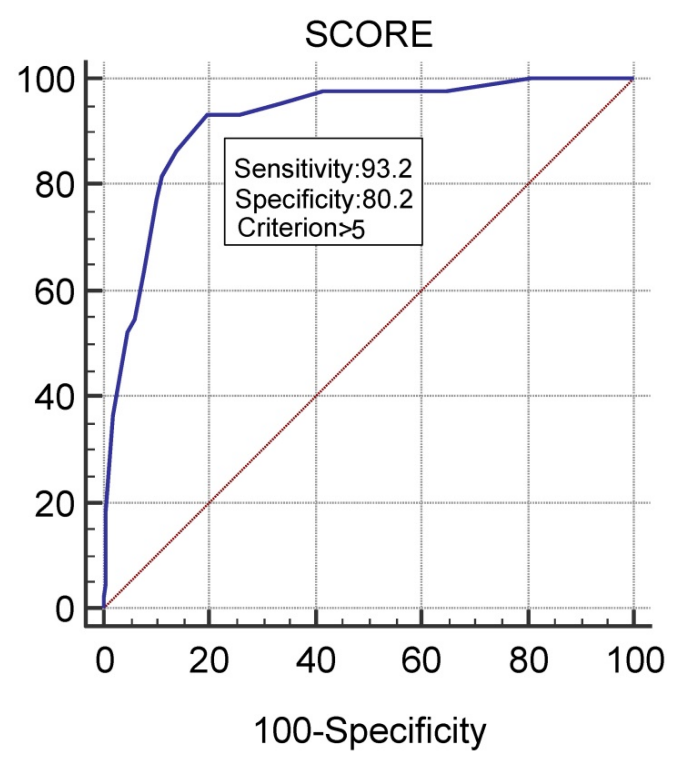

Figure 1. Testing of MMIRI by determining its sensitivity and specificity

\section{Discussion}

The proposed index was created based on retrospective data from our specific hospital environment. As noted, the parameter of sex was excluded from further analysis; based on our findings, its association with infections in our sample was indirect because of its link with the other infection-relevant factors already incorporated into the MMIRI (e.g., the women included in our research more often had a certain kind of catheter). The parameter of type of therapy was also excluded because some regimens used at the time of our study are now obsolete, and the type and sequence of drugs and regimens used today are somewhat different. So far, it is well known that some therapies may be associated with the occurrence of infections (e.g. herpes zoster in patients treated with proteasome inhibitors or high-dose dexamethasone, for which effective antiviral prophylaxis is mandatory). Some recent papers show a possible association of some novel drugs with infection [16-25]. Thus, a possible causative link between certain drugs and infection occurrence must be investigated in further clinical studies, and the results can be incorporated into a subsequent modification of the proposed index.

Because transplanted patients were excluded, this index can be applied only to those patients who are not in the process of hematopoietic stem cell transplant or just post transplantation. Nevertheless, we believe that this index has great potential to help identify patients who have a higher risk for developing infections and to improve outcomes for myeloma patients. According to the present results, the patients with score of 6 or above are candidates for mandatory antimicrobial prophylaxis, which is the main message of this research. MMIRI and the total score can facilitate decision making about the timing of antimicrobial prophylaxis and other anti-infective measures (e.g., immunoglobulin, granulocyte growth factors). This index was created based on retrospective data, and our next step is to test it prospectively with a larger group of patients treated with currently used anti-myeloma drugs and regimens.

\section{Acknowledgements}

This work was supported by the Research Support of the University of Rijeka: grant No. 847.10.1347

\section{Competing Interests}

The authors have declared that no competing interest exists. 


\section{References}

1. Blimark C, Holmberg E, Mellqvist UH, et al. Multiple myeloma and infections: a population-based study on 9253 multiple myeloma patients. Haematologica. 2015; 100:107-113

2. Tete SM, Bijl M, Sahota SA, Bos NA. Immunedefects in the risk of infection and response to vaccination in monoclonal gammopathy of undetermined significance and multiple myeloma. Front Immunol. 2014; 5:257

3. Joshua D, Suen H, Brown R, et al. The T Cell in Myeloma. Clin Lymphoma Myeloma Leuk. 2016; 16:537-542

4. Nucci M, Anaissie E. Infections in patients with multiple myeloma. Semin Hematol. 2009; 46:277-288

5. Park H, Youk J, Kim HR, et al. Infectious complication in multiple myeloma receiving autologous stem cell transplantation in the past 10 years. Ind J Hematol. 2017; 106:801-810.

6. Klein B, Zhang XC, Lu ZY, Bataille R. Interleukin-6 in human multiple myeloma. Blood. 1995; 85:863-872

7. Jego G, Bataille R, Geffroy-Luseau A, Descamps G, Pellat-Deceunynck C. Pathogen associated molecular patterns are growth and survival factors for human myeloma cells through Tool-like receptors. Leukemia. 2006; 20:1130-1137

8. Bohnhorst J, Rasmussen $\mathrm{T}$, Moen $\mathrm{SH}$, et al. Toll-like receptors mediate proliferation and survival of multiple myeloma cells. Leukemia. 2006; 20:1138-1144

9. Bao H, Lu P, Li Y, et al. Triggering of toll-like recptor-4 in human multiple myeloma cells promotes proliferation and alters cell responses to immune and chemotherapy drug attack. Cancer Biol Ther. 2011; 11:58-67.

10. Valkovic T, Nacinovic Duletic A, Petranovic D: Prophylactic broad spectrum antibiotics as a new anti-myeloma therapy. Med Hypotheses. 2013; 81:1137-1140

11. Valkovic T, Gacic V, Ivandic J, et al. Infections in Hospitalised Patients with Multiple Myeloma: Main Characteristics and Risk Factors. Turk J Haematol. 2015; 32:234-242

12. International Myeloma Working Group. Criteria for the classification of monoclonal gammopathies, multiple myeloma and related disorders: a report of the International Myeloma Working Group. Br J Haematol. 2003; 121:749-757

13. Oken MM, Creech RH, Tormey DC, et al. Toxicity and response criteria of the Eastern Cooperative Oncology Group. Am J Clin Oncol. 1982; 5:649-655

14. Durie BG, Salmon SE. A clinical staging system for multiple myeloma. Correlation of measured myeloma cell mass with presenting clinical features, response for treatment and survival. Cancer. 1975; 36:842-854

15. Greipp PR, San Miguel J, Durie BG, et al. International staging system for multiple myeloma. J Clin Oncol. 2005; 23:3412-3420

16. Dimopoulos MA, Palumbo A, Attal M, et al. Optimizing the use of lenalidomide in relapsed or refractory multiple myeloma: consensus statement. Leukemia. 2011; 25:749-760

17. Dimopoulos MA, Leleu X, Palumbo A, et al. Expert panel consensus statement on the optimal use of pomalidomide in relapsed and refractory multiple myeloma. Leukemia. 2014; 28:1573-1585

18. Attal M, Lauwers-Cances V, Hulin C, et al. Lenalidomide, Bortezomib, and Dexamethasone with Transplantation for Myeloma. N Engl J Med. 2017; 376:1311-1320

19. Hoy SM. Pomalidomide: A Review in Relapsed and Refractory Multiple Myeloma. Drugs. 2017; 77:1897-1908

20. Krishnan A, Kapoor P, Palmer JM, et al. Phase I/II trial of the oral ixazomib, pomalidomide, and dexamethasone in relapsed/refractory multiple myeloma. Leukemia. 2017; doi: 10.1038/leu.2017.352

21. Mateos MV, Dimopoulos MA, Cavo M, et al. Daratumumab plus Bortezomib, Melphalan, and Prednisone for Untreated Myeloma. N Engl J Med. 2017; doi: 10.1056/NEJMoa1714678

22. Kropff M, Vogel M, Bisping G, et al. Bortezomib and low-dose dexamethasone with or without continuous low-dose cyclophosphamide for primary refractory or relapsed multiple myeloma: a randomized phase III study. Ann Hematol. 2017; 96:1857-1866

23. Lakshman A, Abeykoon JP, Kumar SK, et al. Efficacy od daratumumab-based therapies in patients with relapsed, refractory multiple myeloma treated outside of clinical trials. Am J Hematol. 2017; 92:1146-1155

24. Bringhen S, De Wit E, Dimopoulos MA. New Agents in Multiple Myeloma: An Examination of Safety Profiles. Clin Lymphoma Myeloma Leuk. 2017; 17:391-407

25. Tzogani K, Camarero Jimenez J, Garcia I, et al. The European Medicines Agency Review of Carfilzomib for the Treatment of Adult Patients with Multiple Myeloma Who Recieved at Least One Prior Therapy. Oncologist. 2017; 22:1339-1346 